\title{
Die verhouding tussen land en ekumene in die Ou Testament en die betekenis daarvan vir vandag
}

\author{
J.L. Helberg \\ Departement Ou Testament \& Nuwe Testament \\ Potchefstroomse Universiteit vir $\mathrm{CHO}$ \\ POTCHEFSTROOM
}

\begin{abstract}
The aim of this article is to determine to what extent God's action with his people is detcmuned spatially and to what extent focus on the land and ecumenicity are contrary, substitutionary. complementary or dialectic concepts. The following questions will be addressed. To what exieni does land play a role in ecumenical relations? To what cxient are these relations detemined structurally or organisationally? To what cxtent is diversing or plurality accommodated? Old Testament matcrial will receive special attention but the line of thought in the New Testament will also be touched upon briefly. Applicd to cument issues the aricle will inter alia pay attention to the question whether the aim of ecumenical reflecrion should be one 'national church' with sister churches in other countries or one world wide church'.

An altempt will be made to indicate that land has an imponant, but at the same time a relotive role, as the latter is especially clcar in the New Testament. Scripture is not essentialb concemed with structural, organisational relations, but with living, personal relations between fiod and man. The way in which relevant issucs are dealt with in the World Council of Churches, cspectally in the light of the 1991 Asscmbly in Canbcra, is also touched upon
\end{abstract}

\section{INLEIDING}

Met land word hier in die eerste plek die land van Israel bedoel. Land in die algemeen sal alleen ter sprake kom in sover dit hiermee verband hou. Met ekumene word bedoel wêreldwye eenheid of samewerking op godsdienstige gebied. en wel volgens Bybelse siening. In Nuwe-Testamentiese taal kan 'n mens praat van die samewerking van alle Christelike kerke in die wêreld. Die artikel wil bepaal in hoever God se handeling met sy volk ruimtelik bepaald is en in hoever landgerigtheid en ekumene teenoor mekaar staande, plaasvervangende, aanvullende of dialektiese begrippe is, waarin nou dié een en dan die ander een domineer. In hoever speel land 'n rol in ekumeniese verhoudinge? In hoever is hierdie verhoudinge struktureel of organisatories bepaald? In hoever word die diversiteit of pluraliteit van land geakkommodeer? Veral die Ou-Testamentiese gegewens sal ter sprake kom, maar die lyn sal ook kortliks deur die Nuwe Testament gevolg word. Baie kortliks toegepas op vandag, wil die artikel onder meer aandag gee aan die vraag of dit om die verhouding van een 'nasionale kerk' met susterkerke in ander lande behoort te gaan, of om een 'wêreldwye kerk'. 


\section{DIE MENS AS VREEMDELING OP DIE AARDE}

Die mens is as beeld van God geskep en het die opdrag gekry om oor al die diere op die aarde te heers (Gen. 1:26-28). Sy opdrag is dus universeel en sluit 'n ekologiese verantwoordelikheid in. Genesis 1 en 2 saamgelees, sê dat die opdrag ook plaaslik is, want die mens is in 'n tuin gestel. In sy opdrag en sy bestaan is twee pole verenig, so ook in sy wese as mens: uit die bodem gevorm (Gen. 2:7), 'n stoflike wese met stoflike behoeftes en verantwoordelikheid, maar tog nie bloot van die bodem nie, want God het self vir hom die lewensasem ingeblaas (Gen. 2:7). Die mens is volgens Genesis 2 in die eerste plek 'n bewerker van die grond, en sy ongehoorsaamheid tref hom dan ook in sy verhouding tot die aarde (Gen. 3:17,18). Tog gaan dit basies om die vervreemding met God. Daar is nie sommer 'n outomatiese verbinding tussen die mens en die aarde nie; daar is vir hom 'n plek gegee. Dit behels dat hy 'n roeping van God en 'n verantwoordelikheid teenoor God het.

Die mens is van die aarde vervreem en is uit die tuin uitgedryf (Gen. 3:17-19,24). Hy is dus nie meer werklik tuis nie maar is ' $n$ vreemdeling. Hier lê die wortel van ekologiese probleme. Om die bekamping van ekologiese probleme in perspektief te sien, moet gelet word op die noue verband tussen die werk van die Woord en die Gees volgens die Skrif. Woord en Gees was werksaam by die skepping (vgl. Gen. 1:2 en die refrein "Toe het God gesê" in Gen. 1; ook Ps. 33:6,9). Albei is soos asem wat uit God se mond kom, en albei word sterk verbind met sy werksaamheid om deur die wind lewe in die natuur te laat uitspruit of te laat verdor (vgl. Jes. 40:6-8). Die werking van die wind en van ' $n$ mens se gees of asem kan nie van die werking van God se Gees losgemaak word nie en kan terselfdertyd nie daarmee geidentifiseer word nie. Dit is hoe tekste soos Psalm 33:6,9; 104:30 en Jesaja 40:6-8 verstaan moet word. Die Gees is die onderliggende dryfkrag by kosmiese werksaamhede. Die siening dat Genesis 1:2 'n stormwind bedoel, is omstrede (Albertz \& Westermann, 1976:729,730) en moet afgewys word, aangesien dit inisiatief aan die wind toeken, strydig met die hele gees van

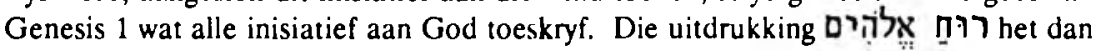
ook nêrens elders in die Ou Testament die betekenis van wind nie.

Die werking van die Woord en Gees by God se skeppings- en regeringswerk wat 'n algemeen universele karakter dra, moet in die lig van die voorgaande bespreking goed onderskei word van die besondere werking, wat nie algemeen van aard is nie maar wedergeboorte en bekering bewerk. Dit is veral in hierdie sin dat die Ou Testament, en in besonder die Nuwe Testament, oor die Gees praat: Dawid bid om die Gees in sy skuldbelydenis oor sy sonde (Ps. 51:11-15); Jesaja 55:7-11 roep op tot bekering, met verwysing na die feit dat die Woord van God nie onverrigtersake na Hom toe terugkeer nie; Esegiël 37:25-29 verbind die werking van die Gees aan die nuwe verbond waarin bekering en innerlike gehoorsaamheid bewerk sal word; en Esegiël 37:12$14,23,24$ praat oor die opstanding van Israel in die ballingskap. Die koninkryk van God word deur Johannes die Doper en Jesus direk verbind met die eis om bekering (Matt. $3: 2 ; 4: 17)$. Ná sy opstanding wys Jesus daarop dat Hy moes ly en opstaan en dat 
bekering van sondes aan al die nasies verkondig moet word (Luk. 24:45-47). Die doop gaan gepaard met die eis om bekering (Hand. 2:37,38). Hieruit is duidelik dat die evangelie van Christus wêreldwyd is, maar nie wêreldgelyk nie.

Hoewel die mens uit die tuin gedryf is en 'n vreemdeling geword het, kry hy tog klere saam as ' $n$ teken van God se ontferming en beskerming. By Kain. wat sy broer vermoor het, kry die straf van vervreemding verdere beslag; hy word 'n doellose swerwer (Gen. 4:12,16). Kain en sy geslagslyn (Gen. 4:24) probeer hulle probleme te bowe kom deur selfverlossing, selfverdediging met behulp van magskonsentrasie: hy bou 'n stad (Gen. 4:17). Lewensverlies en gebroke menslike verhoudinge speel nie 'n rol in sy oorwegings en optrede nie. Hy probeer nie iets daaraan doen nie. Hierdie optrede vorm 'n sterk teenstelling met dié wat Eva en die geslagslyn van Set volg. Vir haar gaan dit om mense en menslike verhoudinge, waarin ook die verhouding met God 'n belangrike rol speel. Sy plaas haar verwagting op die herstel wat deur God bewerk sal word, en wel deur middel van die geboorte van 'n kind (Gen. 4:25). Hierdie kind word Enos genoem, 'n naam wat mens beteken en die konnotasie van swak en verganklik het. Omrede die gevoel van afhanklikheid van God begin die mense in hierdie tyd die Naam van die Here aanroep, dit wil sê Hom gesamentlik aanbid (Gen. 4:26). Ondanks die twee verskillende lyne vanaf Kain, word die mensdom deur Genesis as universele eenheid benader, soos blyk uit die sondvloedgeskiedenis en van die universele evaluering van die mens as sondige wese (Gen. 6-8; veral 6:6-8; 8:21). Dit is ' $n$ mensdom wat tot in sy diepste wese vervreemd is van God maar nogtans sy genade en sorg ervaar. Ondanks sy sondigheid bly die mens nog beeld van God, iemand wat in volle afhanklikheid van God en verantwoordelikheid teenoor Hom, oor die aarde moet regeer (Gen. 1:26-28; 9:6; vgl. Van Selms, 1967:37).

\section{DIFFERENSIËRING EN SKEURING VAN DIE MENSDOM IN LANDE, TALE EN NASIES}

Volgens Genesis 10 het die mensdom onder die seën van God in lande, tale, geslagte en nasies vertak (Gen. 9:1; 10:5,20,31,32). Dit was die vrug van 'n natuurlike historiese verloop van sake en is nie 'n skeppingsgegewenheid nie. Ander skepsele is volgens hulle verskillende groepe se soorte of aard geskep en benader (Gen. 1), maar die mens as een mens of mensepaar. Die mensdom is 'n skeppingsmatige eenheid (vgl. Van Selms, 1967:164-166; hy beperk egter die gebeure te Babel ten onregte tot die mensdom se drang na onsterflikheid (vgl. hierteenoor Stoevesandt, 1991). Die nasies vorm nie geslote, eksklusiewe eenhede nie, maar is deel van een groot familie. Hoewel die mens in ' $n$ bepaalde gebied gestel is om daar te woon, is hy nie daar afgegrens teenoor ander mensegroepe nie. Die aarde en die tuin was 'n woonplek vir die mensdom as geheel. Daarmee is die betekenis van 'n bepaalde woongebied gerelativeer in sy verhouding tot menslike verhoudinge. Tegelykertyd het die mens vir sy woongebied 'n verantwoordelikheid teenoor God.

Die mensdom by Babel is geinteresseerd in magskonsentrasie. Hulle wil vir hulle ' $n$ 
stad bou met 'n toring waarvan die punt tot in die hemel reik (Gen. 11:4). Met hierdie tegniese, organisatoriese en administratiewe magskonsentrasie wil hulle vir hulle 'n naam mak en verhoed dat hulle oor die aarde versprei en dus onbeskermd staan. Hierdie optrede onderstreep egter juis hulle aardgebondenheid. Genesis 11 laat sien dat die verspreiding van die mensdom nie slegs 'n differensiëring was nie maar ook 'n skeuring. Die twee hoofstukke saam sê dat die bestaan van nasies en lande 'n positiewe asook 'n negatiewe betekenis het. Die bestaan van verskillende nasies as sodanig is nie voordelig of 'n probleem nie; dit hang af van die oorweging en dryfkrag agter die soeke na eenheid of die veelheid. Die gebeure by Babel vergestalt die tipiese menslike soeke na eenheid en mag deur onpersoonlike metodes; die verhouding met God en met ander mense word verbygegaan.

\section{DIE GODDELIKE VOORSIENING VAN 'N WARE EENHEIDSFAKTOR VIR DIE MENSDOM}

God betoon Hom as die God van die hele aarde, die magtige en universele God. Die mens is aardgebonde, ook sy gode; hulle is gebiedsgode of landgode of stadsgode. Daarom streef die mens daarna om uit te styg na hoër sfere; sy bouwerk moet reik tot in die hemel (Gen. 11:4). God daarenteen is onbeperk, sowel ruimtelik as in mag. Hy daal uit die hemel neer en tree daadwerklik op; Hy verstrooi die mensdom oor die hele aarde en dit is gedaan met hulle eenheid en mag (Gen. 11:5-8). Ook gee Hy'n antwoord vir die mens se eenheidstrewe en die antwoord is nie 'n anti-stadsoptrede nie: dit is nie die stad (beskawing) wat aan die wortel van die probleem lê nie (vgl. byvoorbeeld Stek, 1978:141,144 oor Rousseau). 'n Stad, Jerusalem, verkry byvoorbeeld later wel 'n belangrike betekenis in die weg van God met sy volk. Tog gee God nie 'n stad as eenheidsfaktor nie, maar 'n mens, en dit behels 'n verhouding met daardie mens in sy verhouding met God. God roep vir Abraham en beloof dat in hom al die geslagte van die aarde geseën sal word. Hierdie seën impliseer dat al die geslagte van die aarde Abraham erken as iemand wat in 'n besondere verhouding met God staan; God wat so wonderlik met hom en deur hom gehandel het. Dus, die seën impliseer geloof in God. Die gedagte is nie bloot dat alle nasies hulleself aan Abraham se voorspoed sal meet nie (vgl. Vriezen, 1966:83) - God se antwoord met die roeping van Abraham is ' $n$ implisiete veroordeling van ' $n$ nasionalisme wat ' $n$ bloed-en-bodembenadering het, sowel as van 'n internasionalisme wat tegniese, ekonomiese, organisatoriese en administratiewe magskonsentrasie as benadering het.

Die Goddelike belofte om aan Abraham 'n land te gee (Gen. 12:2), impliseer nie dat 'n plattelandse bestaanswyse die antwoord is in teenstelling met 'n stedelike bestaanswyse soos dié van Babel nie. Abraham moet sy land en alles verlaat. Hy moet met die hele ou bestaanswyse breek en 'n lewe begin waarin die geloofsverhouding met God die beheersende is. Die aartvaders bly dan ook aanvanklik vreemdelinge in die beloofde land. Hulle het genoeg aan God self. Die land is ' $n$ teken en bewys van hierdie diepere rykdom of gawe, en die vreemdelingskap in die beloofde land rig hulle verwagtings op die belofte van die grotere rykdom wat nog op vervulling wag (vgl. 
Calvyn. 1986:596,597; De Greef, 1984:120-122,130-132,262). Voor die gebeurtenis by Babel het die mensdom reeds in lande gewoon (Gen. 10,11). Nou word $n$ bepaalde land, die beloofde land, 'n simbool van rus vir die mens wat ' $n$ vreemdeling op die aarde geword het deur sy sonde en vervreemding van God. Die rus en vrede lé dus nie in die land as sodanig nie, maar in die verhouding met God en is ' $n$ herinnering aan die onversteurde situasie in die tuin van Eden. Die land het dan ook alleen waarde in sover die mens se herstelde verhouding met God daarin tot vergestalting kom deurdat hy met God lewe. Net een land het hierdie besondere betekenis gekry. Die ander lande se betekenis word sedert hierdie gebeurtenis in die Ou Testament positief of negatief geëvalueer volgens die verhouding waarin huile tot hierdie land staan. Met die koms van Christus is hierdie betekenis tot vervulling gebring en het dié besondere betekenis verdwyn (Gal. 3:27-29; 4:1-7; Filip. 3:20: Hebr. 11:9.16).

Genesis 12:2,3 benadruk die indiwidueel persoonlike aspek, soos gesien in Abraham se direkte persoonlike verhouding met God, maar tegelykertyd ook die universele aspek, soos blyk uit die belofte van universele seën in en deur Abraham. Abraham se verhouding met God is dus nie indiwidualisties nie en is ten diepste nie groepsbeperk of geïsoleerd nie. Verder, ál wat meegedeel word, is: "God het vir Abraham gese", sonder vermelding van enige kultiese of ande: seremonie of bykomstigheid - net die gesproke woord van God (vgl. Vriezen. 1966:278), Alles rus in God se inisiatief en optrede, sy woord is die dryfkrag van alles.

God se antwoord op die gebeure te Babel is dus om 'n persoonlike eenheidsfaktor te gee: 'n eenheidsfaktor wat saamhang met geloof in God, en om verder vir Abraham uit sy geboorteland weg te stuur met die belofte van 'n nuwe begin in 'n nuwe land. Abraham, en so elke gelowige, is 'n gestuurde eerder as 'n gevestigde, 'n vreemdeling eerder as 'n nedersetter (vgl. Hebr. 11:8-16).

\section{BEVRYDING UTT DIE LAND VAN SLAWERNY}

Die bevryding uit die land van slawerny (Eks. 3) staan sentraal in die geskiedenis van Israel en daar word telkens in die Ou Testament hierna terugverwys (vgl. Vriezen, 1966:209; Von Rad, 1962:175,176). Hierdie gebeurtenis staan trouens meer sentraal as die gebeurtenis van die intog in die land. Die uittog uit Egipte en die intog in Kanaan is nie sonder meer gelykwaardige gebeurtenisse in Israel se geskiedenis nie. Bevryding is nie identies met intog in 'n nuwe land nie. Tussen uittog en intog is daar ander belangrike gebeurtenisse, soos die wetgewing te Sınaï en die trek deur die woestyn (vgl. Stek, 1978:148,149). In die geskiedenis rondom die roeping van Moses (Eks. 3) word duidelik wie en wat God is. Hy is die God wat in ' $n$ verbondsverhouding met Israel staan, soos blyk uit sy selfbekendstelling as die God van Abraham, Isak en Jakob (Eks. $3: 4,15$ ), en uit die uitdruklike verwysing na hierdie verbondsverhouding (Eks. 2:24). Tog is Hy 'n God wat so uniek en vrymagtig is dat Hy nie in enige formule, omskrywing, of selfs naam, saamgevat en ingeperk kan word nie. Hy kan slegs in terme van Homself geken word. Hy is wat $\mathrm{Hy}$ is. Dit word uitgedruk in sy selfbekendstelling "Ek 
is wat Ek is", en "Ek is" (Eks. 3:14), waarin sy dinamiese en beskermende teenwoordigheid aangedui word (vgl. Helberg, 1988 vir bespreking en tersaaklike literatuur).

Die doel van die bevryding is dat Israel vir God 'n koninkryk van priesters sal wees, almal konings en priesters, met persoonlike toegang tot God as lede van een volk (Eks. 19:5,6). Nie die plek waarheen Hy hulle bring, is die eintlike doel nie, maar dat $\mathrm{Hy}$ hulle na Hom toe bring (Eks. 19:4). Hierdie doeleinde kry gestalte daarin dat Israel God dien volgens sy gebooie, en in sy gebooie gaan dit nie bloot om kultiese handelinge, handelinge rondom erediens nie, maar veral om die regte verhouding tot God en die naaste: die regte verhouding met woord en daad. God is die God wat die gebeurtenisse en die geskiedenis bepaal, die God wat sy volk uit Egipte verlos en Hy verwag dat hulle as sy volk sal leef deur sy gebooie te onderhou - uit dankbaarheid vir die redding (Eks. 20:2). Wanneer Israel die eerste opbrings van die seisoen se oes kom offer, is hulle fokus nie op die bodem gerig nie; daar word nie gedank vir die vrugte van die land nie, maar die Gewer word gedank vir wat $\mathrm{Hy}$ in die geskiedenis gedoen het ter vervulling van sy belofte om die land te gee (Deut. 26; vgl. Von Rad, 1968:114). Die gebeure is nie geosentries nie, maar histories; nee, nie histories nie, maar teosentries.

Die vyfde gebod bewys die primêre betekenis van die gebooie in verhouding tot die land. Die gebod is nie om die land te besit nie maar om vader en moeder te eer; die woon in die land is 'n vrug daarvan, genadeloon (Eks. 20:12). Die land het nie betekenis op sigself nie; die land het geen selfstandige betekenis behalwe dat dit die ruimte bied waarbinne Israel God kan dien deur hulle ouers te eer en al die ander gebooie na te kom, nie. Die wet is dus nie geosentries nie.

Die land beklee in der waarheid 'n sekondère plek in die geskiedenis van Israel. Israel is nie in die land gebore nie maar was alreeds wesenlik 'n volk van God toe hulle in die land gekom het. Die verbondsluiting het alreeds plaasgevind (teenoor 'n eksiliese datering, vgl. Bright, 1976:40-42; Helberg, 1990a:81-84) en Israel het alreeds die tien gebooie ontvang. Die saak waarom dit gaan, is die verhouding tot God volgens hierdie gebooie. Dit is om hierdie rede dat Israel se woestynverblyf (die teenoorgestelde van 'n landverblyf) wat op die uittog volg, deur die profete as ideale tyd gesien word - 'n leerskool in die geloofsverhouding met God.

\section{VESTIGING EN VERBLYF IN DIE LAND}

Die boek Josua handel oor die vestiging in die land. Die verowering van Jerigo wys dat God met mag en geweld opgetree het (Jos. 2). Dieselfde geskiedenis wys egter dat God ook op 'n ander wyse oorwin. Hy verander mense se gesindhede en laat hulle tot geloof in Hom kom (byvoorbeeld die Kanaänitiese prostituut Ragab; vgl. ook Hebr. 11:31). Die koningstyd is die tyd van konsolidasie in die land en 'n tyd van landsuitbreiding. Die vervulling van die landsbelofte gebeur op so 'n manier dat dit ' $n$ verdere belofte in vooruitsig stel ( $\mathrm{vgl}$. Von $\mathrm{Rad}, 1965: 320)$ en veroorsaak dat Israel nooit 
werklik die eindpunt van volkome rus bereik nie. Hulle bly as 't ware op reis na daardie bestemming toe; dit bly as 't ware deel van 'n belofte waarvan die vervulling nog in die toekoms wink (vgl. Helberg. 1990a:33). Die profete bly Israel dreig met die verlies van die land omrede hulle sonde: hulle aanbid God nie as die enigste God nie; verder is Israel se sonde ook geleë in morele en etiese oortredinge, asook in onreg en harteloosheid op sosiaal-maatskaplike gebied (Jes. 1:17-23; Jer. 7:5-10; Miga 6:6-8).

Die profete het ook 'n sterk universele visie. Hierin tree 'n sterk antitese teen die ander nasies na vore, soos die profesie teen die nasies getuig (Jes. 13-23; Jer. 46-51; Eseg. 25-32). Daar is egter ook positiewe vooruitsigte vir die nasies as deelhebbers aan die Woord van God (Jes. 2:2-4; Miga 4:2-4). Die Persiese koning Kores word gesalfde van Jahwe genoem (Jes. 45:1), Egipte en Assirië sal selfs 'n plek naas Israel kry as volk van Jahwe (Jes. 19:26), die profeet Jona word deur God berispe omdat hy meen dat God nie ontferming aan die heidense nasies betoon nie (Jona 4:9-11). In die beloofde land moes Israel ook 'n roeping op ekologiese gebied nakom en hulle moes onder andere die Sabbatjaar hou om te verseker dat die landbougrond nie uitgeput raak nie (Lev. 25; Num. 36:4). Die mens is trouens 'n regeerder wat rentmeester is en verantwoording teenoor God moet doen (vgl. Gen. 1:26-28; 2:15).

\section{BALLINGSKAP EN TERUGKEER}

Land en volk het 'n noue verbinding met mekaar. Wanneer Israel weens hulle sonde uit die land uit weggevoer word, beteken dit in werklikheid dat Israel sterf. Israel moet deur God lewendig gemaak word (Eseg. 37) en hierdie lewendmakende herstel hang saam met terugkeer na die land toe (Eseg. 37:12-14). God makk nie 'n landlose nuwe begin met Israel nie; tog moet Israel goed begryp dat God nie aan die land of Jerusalem gebonde is nie - Hy is nie die Landgod, of die Stadgod nie. Sy heerlikheid of magtige teenwoordigheid wat veral in Jerusalem geopenbaar is, vertrek saam met die ballinge na die land van die Babiloniërs (Eseg. 1,10,11). Die agtergeblewenes word skerp berispe omdat hulle aanneem dat God daar by hulle is en nie by die ballinge nie (Eseg. 11:14,15). Die boek Klaagliedere beklaag die troostelose toestand van Jerusalem vanweè die ballingskap maar laat ook sien dat die eintlike saak nie die terugkeer na die land toe is nie, maar na God toe - bekering moet dus plaasvind (Klaagl. 5:21; vgl. Helberg, 1990b:381,382).

Aangesien Jerusalem die militêre, staatkundige, finansiële en godsdienstige sentrum is, het die stad Jerusalem 'n simbool van al hierdie aspekte geword en langsamerhand 'n prominenter plek ingeneem as die land (vgl. Jes. 2:2-4; Miga 2:2-4; vgl. Helberg, 1990a:78; Clements, 1965:76,79-85). Die Ou-Testamentiese begrip van Israel se bestaan is nie bloot nasionaal bepaald, sodat Israel vir homself leef en ander volke en lande 'n geslote, onafhanklike bestaan moet voer nie. Israel se geskiedenis bly hom afspeel binne die raamwerk van die belofte dat alle nasies in Abraham die seën sal vind (Gen. 12:2,3). Veral in Jesaja 40 e.v. is daar 'n sterk universele perspektief en het die woord vir land ( $Y$ TX) oorwegend die betekenis aarde (vgl. Hamlin, 1982:105-108). 
Jesaja 40 e.v. wys ook dat die Woord van God vir ewig bly. Die mens daarenteen vergaan, want hy is sondig (Jes. 40:6-8; Ps. 90:10,11). Sy sondigheid maak van hom 'n balling, 'n swerweling - fisies en geestelik (vgl. ook 4).

\section{DISSIPELS TOT AAN DIE EINDES VAN DIE AARDE}

Die prominente lyn van die uittog uit Egipte word ook in die Nuwe Testament voortgesit. By die bedreiging van Jesus se lewe deur Herodes word vermeld: "Josef het toe opgestaan en die Kindjie en sy moeder geneem en na Egipte toe vertrek en daar gebly tot die dood van Herodes. So is vervul wat die Here deur 'n profeet gese het: Uit Egipte het Ek my Seun geroep" (Matt. 2:15). Die vervulling word verbind met die uitgaan uit Egipte, nie met die ingaan in die land Israel nie. Die klem val nie op die land Israel as lewensruimte nie, nie op die geografie nie, maar op die historiese vervulling van die Woord, en wel op die feit dat dit in Hom vervul is (vgl. ook Snyman \& Floor, 1969:38 en die analoog in Deuteronomium 26 - pt. 5).

Aangesien die belofte van verlossing in Christus vervul geraak het, het die besondere betekenis van die land verval en het die betekenis daarvan oorgegaan op die aarde, meer bepaald die toekomstige, nuwe aarde (Matt. 5:5). Jesus en Israel tree wel nie in 'n lugleegte op nie, maar in ' $n$ land en op bepaalde plekke met bepaalde name. Hierdie historiese aspek van Jesus se koms en optrede het dan ook betekenis vir kerkwees (vgl. Küng, 1971:44). Die plekke het egter nie betekenis op sigself nie, maar alleen omrede God se vervulling van sy beloftes en omdat Jesus daar opgetree het (vgl. Davies, 1974:252). Die feite van die menswording van die Woord en die liggaamlike opstanding van Jesus wys dat materiële dinge wel belangrik is. Tog word land deur Hom gerelativeer: anders as die pasga in die Ou Testament, hoef die Nagmaal nie op 'n bepaalde plek gevier te word nie, en die opstandingsliggaam sal radikaal anders wees as nou (vgl. Helberg, 1990a:120,121). Anders as by die Pasga is die klem nou nie op uittog uit ' $n$ land en op 'n nasionale of uiterlike vyand nie, maar op die vyand in eie kring en in eie boesem. Die land tree nou op die agtergrond en die geestelike koninkryk van God tree op die voorgrond (vgl. Opperman, 1987:142 oor Hand. 17:26). Anders as die aartsvaders verlang Paulus nie om met sy dood by sy voorvaders begrawe te word nie, maar om by Christus te wees (vgl. Davies, 1974:213,220). Die vaderland van die gelowiges is bo, waar Christus is en waarvandaan ons Hom verwag (Fil. 3:20; vgl. Oosterhoff, 1973:39,40; Helberg, 1990a:124). Die fokus vir die Nuwe-Testamentiese kerk is op die koninkryk van God; daarom is die kerk nie 'n lokaliteitskerk, soos landskerk of volkskerk of groepskerk nie, maar volk van God, saamgebind deur geloof in God deur Jesus Christus, ongeag plek of volk.

By die pinkstergebeurtenis is daar geen sprake van die land nie. Die Gees is nie op die land uitgestort nie en is nie gegee om mense aan die land te verbind nie, maar aan Jesus Christus en aan mekaar in die gemeenskap van die gelowiges. Dit kom onder andere na vore in 'n sigbare eenheid, soos daaruit blyk dat die Gees nie op groepe afsonderlik uitgestort word nie. Tegelykertyd word die natuurlike verskeidenheid 
geakkommodeer deurdat die teenwoordiges elkeen die evangelie in sy eie taal hoor (Hand. 2). Die Gees word uitgestort om hulle tot 'n nuwe lewe te bring, 'n lewe van gehoorsaamheid aan sy gebooie. Hierdie lewe van gehoorsaamheid geld nie vir Israel alleen nie; daar moet volgelinge van Jesus gemaak word tot aan die eindes van die aarde en hulle moet geleer word om alles te onderhou wat $\mathrm{Hy}$ sy dissipels geleer het, insluitende dat Hy die enigste Here en Verlosser is (Matt. 28:19; Hand. 2:36). Net soos by Sinaï lè die klem op die onderhouding van die gebod: dit gaan nie om gewelddadige of uiterlike verowering van lande of gebiede nie. Hier is sprake van 'n verowering van binne uit, soos by Ragab tydens die intog ın Kanaản. Christus as Koning proklameer sy ryk, maar as Konıng in liefde. Die gebooie, trouens die hele $\mathrm{Ou}$ Testament, word deur Hom saamgevat in die gebod van die liefde (Matt. 22:37-40). Die volgelinge moet dus geleer word dat die Ou Testament saamgevat is in Jesus Christus, soos vergestalt in sy geboorte. krusiging. opstanding. hemeivaart en wederkoms.

Hierdie aspek van die wederkoms (vgl. byvoorbeeld Matt. 28:20) gee aan die evangelieverkondiging 'n toekomsgerigtheid. Dit gaan om meer as hier en nou. Die eintlike vervulling wag nog in die toekoms, en is van ' $n$ ander aard as die huidige. Dit geld van die land (Matt. 5:5) en van hemelse burgerskap (Fil. 3:20). Volgens Calvyn (vgl. Bohatec, 1950:427) het die land nie 'n selfstandige betekenis nie. In die Ou Testament word beeldend oor die heil gepraat: die geestelike heil is met sulke voorbeelde en simbole afgeskadu. In die inbesitneming van die land kon Israel die toekomstige erfdeel as ' $t$ ware in 'n spieel sien. die erfenis waarvan hulle geglo het dat dit vir hulle in die hemele voorberei is (Calvyn, 1986:596-598). Kanaân is beeld van die hemelse erfenis; hemels nie as absolute teenstelling met aards nie, maar insluitende sonde en verganklikheid (vgl. byvoorbeeld De Greef. 1984:120-122.130-132.262).

Uit die opdrag om volgelinge te maak, blyk verder dat die koninkryk van Christus 'n universele koninkryk is maar tog slegs vir dié wat glo. Voorts is daar nie sprake van een struktuur, 'kerk', waartoe hulle vergader moet word nie: dit gaan om die gelowiges se persoonlike verhouding en lewe met Christus en om die gemeenskap van die gelowiges ("Waar twee of drie in my Naam saam is, daar is Ek by hulle"; Matt. 18:20). Waar die samekoms van meerdere groepe vermeld word, word dit altyd gedoen met die meervoud kerke (gemeentes), nie met die enkelvoud kerk (gemeente) nie (vgl. Snyman, 1977:38,39; Du Plooy, 1982:81-111). Die Woord is die eenheidsfaktor. Die ekumeniese taak van die gelowiges is om in diens van daardie Woord te wees en nie om hulle eie projek of aktiwiteit ten uitvoer te bring of om hul mening te vestig nie.

\section{DIE VERIIOUDING TUSSEN IAND, STAAT EN EKUMENE}

Von Rad (1962:121,122) se uitgangspunt dat Israel sy God in die eerste plek as Verlossergod geken het, word tereg deur baie teoloë verwerp. Hulle wys op God se hoedanigheid as Skepper en op die daarmee samehangende verantwoordelikheid van die mens teenoor die skepping. Van der Woude (1969) wys byvoorbeeld daarop dat 
die psalmdigters die skepping besing vir wat dit op sigself is en nie bloot vanuit verlossingsoogpunt nie. Von Rad (1962:110-112) se benadering is nie alleen soteriologies nie, maar ook vergeestelikend in die sin dat dit volgens hom in die Ou Testament gaan om verkondiging, kerugma, en nie soseer om geskiedenis nie. Hierteenoor benadruk Brueggemann (1978:1-14) die betekenis van die materiële soos die land in die Ou Testament. Land is plek gevul met geskiedenis en die mens se probleem is ongeworteldheid eerder as betekenisloosheid. Brueggemann lê die klem egter tog eerder op die sosiologiese aspek as op die geografies-historiese aspek, soos blyk uit sy betrekking van die land op woonbuurtes (Brueggemann, 1978:92-194). Gottwald (1975) benader die Ou Testament sterker sosiologies as teologies en beskou selfs die Godsbegrip by Israel as die vrug van sosio-ekonomiese faktore. In werklikheid is die Ou Testament egter nóg materialisties nóg vergeestelikend (vgl. Bright, 1953). Dit gaan nie om die geskiedenis as sodanig nie; nie om 'n aaróse ryk nie, maar om die koninkryk van God. Die koningskap in Israel is dan ook 'n sekondêre verskynsel en het ná die wegvoering in ballingskap in 'n groot mate sy belangrike betekenis verloor.

In die tyd rondom sowel die Ou-Testamentiese as die Nuwe-Testamentiese godsvolk se geboorte, die uittog en die koms van Jesus, het die verbondsvolk nie staatkundige selfstandigheid geniet nie, maar het hulle onder ander owerhede gestaan. Ná die val van Jerusalem en die volk se wegvoering in Babiloniese ballingskap was dit prakties met Israel se koningskap en met staatkundige selfstandigheid verby. Die verwagting is van toe af sterk gevestig op die komende Messias, iemand wat die historiese situasie sou transendeer (vgl. byvoorbeeld Von Rad, 1962:351). Die koninkryk van God is anders as 'n aardse koninkryk; daarom is staatkundige selfstandigheid nie 'n wesenlike voorwaarde vir die volk van God se bestaan nie, ook nie vir kerklike bloei nie (Helberg, 1990a:122), en ewe-eens nie vir beoefening van ekumene nie.

\section{DIE HUIDIGE STAND VAN SAKE BINNE DIE WeRELDRAAD VAN KERKE}

Verwikkelinge in die WRK, as die grootste en invloedrykste liggaam, gee 'n aanduiding van die huidige tendense wat vir ons onderwerp belangrik is, al is die WRK nie 'n eenheid met eenvormige denke nie. Die benaderings van Berkhof (1973) en Moltmann (1977) wat belangrike invloed op die benadering in die kringe van die WRK uitoefen, is ter sake; en verder artikels in reaksie op die laasgehoue byeenkoms te Canberra en afkomstig van persone wat een of ander verband met die beweging het (vgl. ook ander artikels in die WRK se twee tydskrifte, The Ecumenical Review en Intemational Review of Mission). Die byeenkoms in Canberra het veral gestalte gegee aan die WRK se strewe om die hele skepping in die fokus te hê en om dit teologies te fundeer; vandaar die tema 'Kom, Heilige Gees - hernuwe die hele skepping' (vgl. Castro, 1991:2). Hierdie byeenkoms het veral van die kant van die Griekse en Oosterse Ortodokse Kerke ernstige vrae oor sinkretisme ontlok, in besonder weens die optrede van Chung. 
Berkhof (1973:50), voormalige president van die WRK, het 'n kosmiese in plaas van 'n kruis- en inkarnasiebenadering (vgl. Van der Westhuizen, 1989:515,518,519; Helberg, 1991:495): Christus is normatief maar nie eksklusief nie. By Moltmann (1977:127) druk die stoflik-horisontale verhoudinge die verhouding met Christus self op die agtergrond - die kerk is daar waar Christus is, en Christus is in die geringstes van die mensdom. By Chung (1991:1-3) vervaag die grens tussen die Gees van God en die gees van volke en selfs die natuur. Sy doen onder andere 'n beroep op die gees van Ghandi, die inheemse volke en die reënwoude, oral waar bevryding is - tekens van die werking van die Heilige Gees.

Die meeste bogenoemde artikels tree in die bres vir Chung (o.a. Raiser, 1991:347-354; King, 1991:356-360. Vir ander menings, vgl. Helberg, 1991:495). Daar word veral gestel dat die teologie en die kerklike rigting tot dusver gedomineer is deur 'n Europese of Westerse benadering waarin leerstellings eerder as geloof geld, met verdeling en skeurings as gevolg. Daar moet 'n universalisering van die teologie kom (vgl. byvoorbeeld King, 1991:356-360). Die klem word veral gelê op 'n Trinitariese benadering ter integrering van die ekologiese, sosiale, ekonomiese en geestelike behoeftes van die menslike lewens in die wêreld. Met hierdie benadering word besondere insette verwag van die Ortodokse Kerke. Volgens Raiser (1991:347-354) is die bevryding van die Westerse binding veral noodsaaklik in die lig van die krimping van getalle en invloed. Tans kom die groei en die sendingywer veral uit die Derde Wêreld, maar die verskil in benadering bring reeds spanninge in die WRK. Die inheemswording van die kerk vereis dat groot erns gemaak word met die betrokke kulture, hoewel hulle ook deur die evangelie getransendeer moet word. In verband met die inheemswording word daar egter selfs gepraat van 'n voortgaande inkarnering in die bestaande kulture. Die proses van 'vertaling' affekteer ook die 'inhoud' van die evangelie. Tsetsis (1991:87,88) wys daarop dat 'n groeiende aantal Christenteoloë vandag die finaliteit of finale normatiwiteit van Christus en die Christendom bevraagteken. Hoewel daar in die WRK gestreef word na eenheid van die kerk, word besondere waarde geheg aan die kontekstualisering van kerk en teologie en is daar 'n weerstand om hierdie teologieë in een sisteem te verenig (vgl. byvoorbeeld Irwin, 1991:68,70, 71, 75; Raiser, 1991:347-354). Vischer (1991:95-97) beklemtoon verder die belangrikheid van territoriale kerke, elk met sy eie probleme wat eie inisiatiewe, maar ook bo-nasionale samewerking vereis.

Verder blyk daar in WRK-kringe 'n groeiende affiniteit vir die natuur en die eie bodem te wees; groot klem word gelê op die mens se verwantskap met die bodem. Tereg waarsku Newbegin (1991:5-10) teen bewegings wat ons uitnooi om weer deel van die natuur te word. Die natuur is nie 'n bron van etiek nie. Die modernisme, asook die indiwidualisme, met sy gebrek aan 'n etiese grondslag en dryfveer vorm die oorwegende aanslag teen die regte benadering van die ekonomie, tegnologie en natuur. 


\section{SAMEVATTING EN GEVOLGTREKKING}

Die mens is geskep uit die aarde en is plekgerig. Tog is hy geskep as die beeld van sy Skepper en het hy ' $n$ universele roeping ten opsigte van die aarde en sy naaste. Daar is nie grond om net die verlossing van die mens se siel belangrik te ag nie, maar ook nie vir'n soort identifisering tussen die Gees se werk en die kosmos, soos die neiging binne die WRK is nie. So 'n uitgangspunt relativeer die unieke diens van die ware God en verabsoluteer die natur ten koste van die mens se heerskappy en sy behoeftes. Weens sy sonde het die mens vervreemd geraak van God sy Skepper, en daarom ook van die aarde waaruit hy gemaak is, en van sy naaste; vandaar die onderlinge vyandskap tussen volke en lande. Land was vir Israel 'n teken van rus van die sondige vervreemding, 'n teken van die liefde en sorg van God, maar was nie bedoel vir selfsugtige eksploitasie of vir selfgenoegsame isolasie nie - wel vir universele, ekumeniese diensbaarheid.

God is nie ruimtelik beperk nie en daarom is sy weg met sy volk ook wèreldwyd. Hierdie universele ruimte sluk egter nie die mens in sy lokale gevestigdheid op nie, maar laat hom daar tot ryker ontplooiing kom weens die ruimte van visie Die huidige Westerse oorheersing van die Christelike teologie moet nie beantwoord word met 'n akkommodering van die gelowe in die verskillende volke en kulture nie. maar met 'n Skriftuurlike universalisering wat die eis van bekering en reformasie aan almal stel. Die eintlike verdelingspunt by enkeling sowel as by gemeenskap lê in dıe gebrek aan 'n religieus-etiese dryfveer. Nie die bloot geografiese uittog of uitgaan is 'n belangrike Bybelse eis nie, maar die weggaan van die situasie wat 'n mens se diens van God in die weg staan. Ingaan in die land en besit van die land ontvang vir hier en nou nie dieselfde klem as die oproep tot hierdie uitgaan nie, maar is sterker verbind aan die belofte en die toekoms. ' $n$ Gearriveerdheidshouding in verband met land word by die wortel afgesny. Die Bybelse klem val verder op onderhouding van dre gebooie en 'n uiteindelike vredevolle tuiste by Hom

Die volk van God vorm nie $\mathrm{n}$ organisatoriese magskonsentrasie los van of in verbinding met 'n staatsmag nie en word bevry van alle lokaliteitsbepaaldheid en plaaslike, nasionale. landswye en universele struktuurbinding. Die volk van God is wel 'n wêreldwye volk, maar binne hierdie volk is die fokuspunt 'n persoonlike verhouding wat 'n geloofsverhouding impliseer. Die geloofsverhouding veronderstel 'n gemeenskaplike belydenis maar nie n gemeenskaplike land of woongebied nie. Die gemeenskap van die gelowiges kom in die eerste plek plaaslik tot openbaring en word wyer georganiseer sover gemeenskaplike belange dit vereis. Waar die behoefte bestaan, kan 'n algemene sinode (of verwante vergadering) oor die landsgrense gaan. Die klem, organisatories bekyk. lè plaaslik: "Waar twee of drie in my Naam saam is, daar is Ek by hulle" (Matt. 18:20). Volgens die Skrif ken die kerk wel geloofsgrense en mure. Jesus is die enigste Here en Verlosser. Christelike kerke kan nie saam met nieChristelike godsdienste in een juk trek nie. Die Heilige Gees erken wel die eieaard in die eenheid van die gelowiges maar nie ten koste van die eenheid van die kerk nie. 
Christus vat die hele Ou en Nuwe Testament saam in die eis van liefde vir God en die naaste. 'Naaste' is nie eksklusief nie maar inklusief. maar dit fokus nie so op die 'verste' dat die naaste se behoeftes in die slag bly of ondergeskik raak aan dié van die 'verste' en grootste nie. Die universele en ekumeniese taak begin heel persoonlik en plaaslik, by die naaste. Die Woord van God eis alle gelowiges gesamentlik op en gee tegelykertyd aan elkeen ruimte vir sy persoonlike, plaaslike behoefte. Land en ekumene staan volgens die Skrif dus nie teenoor mekaar nie maar is albei diensbaar in die bevordering van die gemeenskaplike behoeftes asook die gemeenskapiike roeping. Hierin kan niemand vryblywend wees nie.

\section{BIBLIOGRAFIE}

ALBERTZ, R. \& WESTERMANN, C. 1976. ni"h Geist. (In THAT. Il Munchen : Kaiser Verlag. p. 726-753.)

BERKHOF, H. 1973. Christelijk geloof. Nijkerk : Callenbach.

BOHATEC, J. 1950. Budé und Calvin: Studien zur Gedankenwell der francoischen Frühhumanismus. Graz : Herman Bóhlans Nachf.

BRIGHT, J. 1953. The Kingdom of God. Nashville : Abingdon Press.

BRIGHT, J. 1976. Covenant and Promise: The Prophetic Understanding of the Future in Pre-exilic Isracl. Philadelphia : Westminster.

BRUEGGEMANN, W. 1978. The Land. London : SPCK.

CALVYN, J. 1986. Institusic van dic Christclike godsdicns. II. Potchefstroom : CJBF.

CASTRO, E. 1991. Editorial. The Ecumenical Review, 43(1):1-3. January.

CHUNG, H-K. 1991. "Come Holy Spirit, Renew the Whole Creation": An Introduction to the Theological Theme. Document No. PL 3.3. World Council of Churches, Seventh Assembly. Canberra. 720 February 1991.

CLEMENTS, R.E. 1965. (ind and Temple: The Idea of the Divinc Presence in Ancient Istacl. Oxford: Blackwell.

DAVIES, W.D. 1974. The Gospel and the Land. Los Angeles: University of California Press.

DE GREEF, W. 1984. Calvijn en hel Oude Testument. (ironingen : Bolland (Proefskrif (ThD) Utrecht.)

DU PLOOY. A. LE ROUX. 1982 Kerkverband: 'n Gereformeerd-kerkregielike studic. Potchefstroom (Proefskrif (Th.D.) - PU vir CHO.)

GOTTWALD, N.K. 1975. Biblical Theology or Biblical Sociology? On Affirming and Defining the "Uniqueness" of israel. Radical Religion, 2(2\&3):42-57.

HAMLIN, E.J. 1982. The Joshua Tradition Reinterpreted. The South East Asia Joumal of Theolog. 23(1):103-106

HELBERG, J.L. 1988 Dic selfhekendstelling van (iod in Eksodus 3 en die betekenis daarvan vir vandag. Korrs, 53(3):28(1)-3(14.

HELBERG, J L. 1990a. Die verbondsvolk se verhouding to sy land: veral in die tyd rondom die wegvocring in Babiloniese ballingskap: Dic Groot Profecic en Klaagliedere. Potchefstroom : Departement Sentralc Publikasies. PU vir CHO.

HELBERG, J.L. 1990h. Land in the Book Lamentations. Zeitschrift fur dic altestamentliche Wissenschaft. 102(3):372-385.

HELBERG, J.L. 1991. 'n Toets vir Gereformecrde ckumene. In die Skriflig, 25(4):485-503.

IRWIN, D.T. 1991. The Banquet of Ecumenial Theology. The Ecumenical Review, 43(1):68-78. Jan.

KIN(;, T.M. 1991. Theological Controversy in Canberra: A Reflection. Intemational Retiew of Mission, 80(319/320): 355-360. July/October

KUNG, H. 1971. The Church. London : Search Press.

MOLTMANN. J. 1977. The Church in the Power of the Spirit: A Contribution to Messianic Eschatology. London : SCM.

NEWBEGIN, L. 1991. A Missionary's Dream The Ecumenical Review, 43(1):4-10. January. 
OOSTERHOFF, B.J. 1973. De beloften aan de aartsvaders. Kampen : Kok. (Verkenning en Bezinning.)

OPPERMAN, W.C. 1987. Land en volk in die Nuwe Testament in die lig van die Areopagusrede (Hd 17:22-31): 'n cksegeties-openbaringshistoriesc studie. Potchefstroom. (Verhandeling (Th.M.) PU vir CHO.).

RAISER, K. 1991. Beyond Tradition and Context: In Search of an Ecumenical Framework of Hermencutics. Intemational Review of Mission, 80(319/320):347-354. July/October.

SNYMAN, W.J. 1977. Nuwe en ou dinge "Uit die skat van die koninkryk". Versamel en aan hom opgedra deur sy oud-studente by geleent heid van sy sewentigste verjaarsdag. Red. P.C. Snyman. Potchefstroom : Pro Rege. (Raad vir Geesteswetenskaplike Navorsing, Publikasiereeks, nr. 56).

SNYMAN, W.J. \& FLOOR, L. 1969. Die koninkryk van God in die Nuwe Testament. (In Du Toit, S. c.a. Dic koninkryk van God. Potchefstroom: Sinodale Deputaatskap belas met ceufeesvierings van die Teologiese Skool. p. 34-58.)

STEK, J.H. 1978. Salvation, Justice and Liberation in the Old Testament. Calvin Theological Joumal, 13(2):133-165).

STOEVESANDT, V.H. 1991. Die eine Menschiheit und die vicle Völker: die biblische Erzählung vom Turmbau zu Babel. Kerygma und Dogma, 37(1):44-61.

TSETSIS, G. 1991. What is the World Council's Oikoumene? The Ecumenical Ricvicw, 43(1):86-89. January.

VAN DER WESTHUIZEN, H.G. 1989. Universalisme en partikularisme vandag. Henomde Teologiese Studies, 45(2):508-526.

VAN DER WOUDE, A.S. 1969. De verhouding Genesis en Exodus. Kerk en Theologie, 20:1-17.

VAN SELMS, A. 1967. Genesis. l. Nijkerk: Callenbach. (POT.)

VISCHER, L. 1991. A Priviledged Instrument of the Ecumenical Movement? The Ecumenical Review, 43(1):90-99. January.

VON RAD, G. 1962. Old Testament Theology. I. Edinburgh : Oliver and Boyd.

VON RAD, G. 1965. Old Testament Theology. II. Edinburgh : Oliver and Boyd.

VON RAD, G. 1968. Das funfte Buch Mose. Deuteronomium. Gottingen : Vandenhocck \& Ruprecht. (ATD.)

VRIEZEN, TH.C. 1966. Hoofdlijnen der theologie van het Oude Testament. Wageningen : Veenman. 